\title{
ANALISIS TENTANG PEMAHAMAN IBADAH MENURUT MAZMUR 50 PADA MAHASISWA STAKN KUPANG
}

\author{
Marsi Bombongan Rantesalu \\ Sekolah Tinggi Agama Kristen Negeri Kupang \\ marsibombongan@gmail.com
}

\begin{abstract}
Worship is a basic need for every Christian to draw closer to God. Therefore we need a correct understanding of true worship. This study looks at the level of understanding of students of STAKN Kupang about true worship, that the true worship based on Psalm 50: 1-23 is giving thanks, paying vows, crying out, and living according to God's provision. This study uses a combination of research types. The qualitative method (exegesis) is carried out to get the indicators to be measured. Then proceed with a quantitative approach in the form of a survey to measure the level of student understanding of worship. The results showed that the price of $t$ count $=19.576$ and the price of the $t$ table for a one-tail test with DK $142=0.65566$. The results of the calculation of the level of understanding of students of STAKN Kupang Semester $V$ regarding the concept of worship, according to Psalm 50: $1-23$ is $87.3 \%$.
\end{abstract}

Keywords: Worship, Psalms 50, Understanding about Worship, STAKN Kupang

\begin{abstract}
Abstrak. Ibadah merupakan kebutuhan dasar bagi setiap orang Kristen untuk mendekatkan dirinya kepada Tuhan. Oleh karena itu perlu pemahaman yang benar tentang ibadah yang sejati itu. Penelitian ini melihat tingkat pemahaman mahasiswa STAKN Kupang tentang ibadah yang sejati, bahwa pada dasarnya ibadah yang benar menurut mazmur 50:1-23 adalah bersyukur, membayar nazar, berseru dan hidup menurut ketetapan Allah. Penelitian ini menggunakan tipe penelitian kombinasi. Metode kualitatif (Eksegesa) dilakukan untuk mendapatkan indikator yang akan diukur. Kemudian dilanjutkan dengan pendekatan kuantitatif dalam bentuk survey untuk mengukur tingkat pemahaman mahasiswa tentang ibadah. Hasil penelitian menunjukkan bahwa harga t hitung $=19,576$ dan harga t table untuk one tail test dengan $\mathrm{dk} 142=0,65566$. Adapun hasil perhitungan tingkat pemahaman Mahasiswa STAKN Kupang Semester V mengenai konsep ibadah menurut Mazmur 50:1-23 adalah sebesar 87,3\%.
\end{abstract}

Kata-kata Kunci: Ibadah, Mazmur 50, Pemahaman tentang Ibadah, STAKN Kupang

Mazmur 50 masuk dalam kelompok "mazmur-mazmur kenabian”. Ada yang menyebutnya liturgi (kenabian), liturgi pengadilan kenabian, dan yang lain lagi mazmur pesta. Mazmur-mazmur kenabian tidak mempunyai pola atau jenis. Mazmur 50 sebenarnya memiliki unsur-unsur jenis sidang pengadilan oleh Allah. Dalam teks-teks jenis ini Allah tampil untuk 
mengadili umat-Nya (ay. 4b). Dia tampil sekaligus sebagai hakim (ay. 4), saksi (ay. 7) dan jaksa atau penuduh (ay. 8, 21). Dengan demikian dapat dikatakan bahwa Mzm. 50 mengandung unsur- unsur, baik liturgis maupun kenabian. Pfeiffer mengatakan, "Ada dua tema yang menonjol dalam Mzm. 50 yaitu ibadah yang sejati dan moralitas masyarakat. Hal ini berkaitan dengan hubungan manusia dengan Allah dan hubungan manusia dengan sesamanya."(Pfeiffer \& Harrison, 2009a, p. 171). Menurut Bergant dan Karris, Mazmur ini mengisahkan sebuah upacara di mana Tuhan mengadili umat yang berkumpul di Gunung Sion. Apakah mereka setia kepada perjanjian, secara positif dengan beribadat dan berseru hanya kepada Tuhan saja, secara negatif menghindari pelanggaran terhadap Kesepuluh Perintah (ay. 16-20)? (Bergant \& Karris, 2004).

Khusus Mzm. 50:1-23 ditulis oleh bani Asaf, seorang Lewi yang berkarunia musik dan nubuat. Asaf bin Berekhya bin Simea adalah seorang ahli musik keturunan suku Lewi dari bani Gerson pada zaman raja Daud (1Taw. 6:39). la menulis 12 mazmur dalam kitab Mazmur, yaitu Mazmur 50, 73-83. "Bersama-sama dengan Heman, cucu Samuel, dan Etan merupakan penyanyi utama di Bait Allah. Menurut Sihotang, Asaf adalah penyanyi yang setia pada zaman Daud. la juga seorang hamba Tuhan yang dikaruniai bernubuat (1Taw. 25:1)." (Sihotang, 2006). Asaf adalah pemimpin suku Lewi yang melayani di hadapan tabut Tuhan, $\frac{\text { mengajukan permohonan doa, mengucap syukur dan memuji Tuhan }}{\text { Marsi Bombongan Rantesalu }}$ 
(1Taw. 16:4). (Longman III, 1992). Seperti dikemukakan Wongso, pada waktu kaum Israel kembali ke negara mereka dari Babilonia, terdapat 128 orang keturunan Asaf dalam barisan tersebut. Pada waktu itu dasar Bait Suci Allah diletakkan di zaman Zerubabel bani Asaf dengan membawa ceracap memuji-muji Allah (Ezr.3:10), mereka mengarang 12 buah syair, Mzm. 50, 73-83. (Wongso, 1984)

Umat Israel berulang kali jatuh ke dalam dosa. Kritik atas ibadah yang keliru dan hidup keagamaan yang palsu diungkapkan dalam PL terutama oleh para nabi. Israel dipanggil untuk menyadari sungguhsungguh siapakah sebenarnya Tuhan itu. Mereka telah membawa persembahan kepada Tuhan, tetapi cara hidup mereka tidak berkenan kepada-Nya (Mzm. 50:17-20). Sikap Allah bukan bergantung pada persembahan umat-Nya tetapi Allah lebih menginginkan ucapan syukur dengan segenap hati. (Pfeiffer \& Harrison, 2009a). Dengan demikian, tujuan penulisan kitab ini ialah untuk memberikan kritik terhadap konsep yang keliru orang Israel yang hanya menganggap ibadah sebagai pelaksanaan upacara agama tanpa disertai penyembahan dan pengenalan serta takut akan Tuhan .

Ibadah pada hakekatnya terkait kegiatan manusia kepada Allah (Santosa, 2012). Dari segi etimologi, kata "Ibadah" merupakan terjemahan dari istilah Ibrani yang dalam Perjanjian Lama (PL), yaitu "hdbg" (avodah) dari kata dasar "dbg"(avad), artinya bekerja, mengerjakan, mengabdi, melayani dan beribadat. (Bakker, 2012). Kata office (ibadah) dari bahasa Marsi Bombongan Rantesalu 
Latin officium, berarti pelayanan atau tugas, juga digunakan untuk mengartikan suatu pelayanan ibadah (White, 2011). Dalam Ensiklopedi Alkitab Masa Kini dituliskan bahwa kata "ibadat" Ibrani (avodah) dan Yunani (latreia) berarti pelayanan yang dipersembahkan kepada Allah baik dalam arti ibadat di Bait Suci maupun dalam arti pelayanan kepada sesama. (Douglas, 2003)

Menurut Kamus Besar Bahasa Indonesia, deskripsi kata "ibadah" adalah: Perbuatan untuk menyatakan bakti kepada Allah, yang didasari ketaatan mengerjakan perintah-Nya dan menjauhi larangan-Nya. (KBBI, 2016). Ibadah kepada Tuhan merupakan salah satu kebutuhan dasar manusia. Melalui Ibadah terjadi pertemuan antara Tuhan Allah dan Jemaat. Ibadah juga merupakan perintah Tuhan Allah sebagaimana dikemukakan dalam sepuluh hukum untuk hanya menyembah Tuhan Allah. Untuk itulah Allah membebaskan umat israel dari perbudakan di Mesir supaya mereka beribadah kepada Tuhan Allah. (Sumarto, 2019). Dalam Alkitab Penuntun Hidup Berkelimpahan, yang dimaksud dengan "ibadah" ialah aneka tindakan dan sikap yang menghargai dan menghormati kelayakan Allah semesta langit dan bumi yang agung. Ibadah berpusat pada Allah dan bukan pada manusia. (Stamps, 1999). Selanjutnya Setiawan menuliskan bahwa ibadah menyangkut seluruh aspek kehidupan yang dinyatakan melalui penyembahan (kesediaan mendengar firman Tuhan dan memperhatikan pengajaran-Nya), pelayanan (kebaktian, kegiatan gereja, dll.), pengenalan akan Tuhan, 
takut akan Dia, dan hidup menuruti jalan Tuhan dengan melakukan keadilan dan kebenaran. (Setiawan, 2004)

Menurut dan Pareira, hanya ibadah yang dijiwai oleh pengakuan akan Allah sebagai Allah (ay. 14a) adalah ibadah sejati yang memuliakan Allah. Ibadah yang sedemikian itu akan bermuara atau mempunyai pengaruh dalam hidup. (Barth \& Pareira, 1999). Jadi, ibadah yang sejati adalah ibadah yang berpusat pada Allah yang meliputi aneka tindakan dan sikap yang menghargai dan menghormati kelayakan Allah, menyangkut seluruh aspek kehidupan yang dinyatakan melalui kesediaan memperhatikan pengajaran, pengenalan akan Allah dan melakukan keadilan untuk memuliakan Allah.

Ibadah dalam kitab Mazmur 50 mengandung unsur-unsur, baik liturgis maupun kenabian. Adapun unsur-unsur yang terkandung dalam Ibadah yang Sejati yang meliputi: Mempersembahkan Syukur. Ibadah merupakan bagian sentral dalam kehidupan agama Israel. Ibadah mencakup persembahan syukur. Dalam ayat 14a, "Persembahkanlah syukur sebagai korban kepada Allah". Dalam bahasa Ibrani: hdwt myhle hcbz (zabach elohiym towdah). KJV: Offer unto God thanksgiving.

Kata "mempersembahkan...", bahasa Ibrani "ootb;z" zavakh artinya menyembelih (kurban) ,yakni "bentuk verb, qal imperative masculin, dipakai 134 kali", yang dalam bahasa Inggris offer yang berarti mengorbankan sedangkan kata "syukur...", bahasa Ibrani "hd;wt" todah artinya nyanyian syukur, kurban syukur, terima kasih (Bakker, 2012) yakni Marsi Bombongan Rantesalu 
bentuk noun, feminine, singular, absolut, dipakai sebanyak 32 kali. Dalam bahasa Inggris "thanksgiving yang berarti rasa syukur". Jadi mempersembahkan syukur berarti memberikan pengakuan dan pujian kepada Tuhan.

Menurut Barth dan Pareira, nyanyian pujian sebagai korban merupakan sikap batin yang benar dalam membawa korban. Sikap batin yang benar itu ialah yang mengakui Allah sebagai Allah dan segala sesuatu adalah milik-Nya. Pada-Nya Israel (dan semua manusia) bergantung sepenuhnya. Karena segala sesuatu adalah milik Allah, maka sikap yang benar itu tidak lain dari bersyukur dan memuji Allah karena segala anugerah itu (bnd. 119:108: "Terimalah dengan rela ya Tuhan, korban doa-doaku; TB: "Kiranya persembahan sukarela yang berupa pujipujian berkenan kepada-Mu ya Tuhan"). (Barth \& Pareira, 1999)

Allah mengumumkan kekeliruan pandangan ibadah umat Israel. Mereka telah memberikan binatang korban kepada-Nya, seolah-olah Allah membutuhkan korban tersebut. Simanjuntak menuliskan, "Ibadah yang benar tidak terjadi dalam hal mengorbankan daging dari binatang, tapi dalam jawaban syukur pribadi (mungkin saja dalam bentuk korban yang layak dan wajar) dan kesetiaan yang kokoh kepada Allah. (Simanjuntak, 1985). Lanjut Pfeiffer mengatakan bahwa sikap Allah bukan bergantung pada persembahan umat-Nya. Dia lebih menginginkan ucapan syukur dengan segenap hati. (Pfeiffer \& Harrison, 2009b). Umat Tuhan mempunyai banyak hal untuk mengucap syukur kepada Tuhan. Seperti Marsi Bombongan Rantesalu 
yang dijelaskan oleh Longman, "Kita mempunyai lebih banyak hal untuk mengucap syukur kepada Tuhan dari pada bangsa Israel masa lalu." (Longman III, 1992, p. 168). Dengan demikian, mempersembahkan syukur berarti bersyukur dengan segenap hati kepada Tuhan karena kebaikanNya yang diwujudkan melalui sikap hidup sehari-hari bukan mempersembahkan korban binatang.

Membayar Nazar. (Ayat 14b). "Dan bayarlah nazarmu kepada Yang Mahatinggi". Dalam KJV: "and pay thy vows unto the most High".

Kata Ibrani Piel: mleefi (syillem) artinya menyelesaikan, membalas, membayar nazar (ganti rugi) (Bakker, 2012) yaitu bentuk verb, piel imperative masculine singular, dipakai 116 kali sedangkan kata rdn (neder) artinya nazar, janji yang dalam bahasa Inggris "thy vow" yang berarti sumpah, janji”, (Strong, 1986) dipakai sebanyak 60 kali.

Pemazmur juga menyerukan supaya nazar yang diucapkan di hadapan Tuhan dibayar dengan penuh pengucapan syukur atas rahmatNya. "Persembahkanlah syukur sebagai korban kepada Allah dan bayarlah nazarmu kepada yang Mahatinggi" (ayat 14). Para pemazmur bersyukur kepada Tuhan bukan hanya karena berkat-berkat materi dan alamiah, melainkan karena berkat-berkat rohani juga. Menurut Rowley, "Kurban pembayaran nazar merupakan penggenapan suatu perjanjian bersyarat: "Kalau terjadi demikian, maka aku akan mempersembahkan kurban”. Baik pengucapan syukur maupun pembayaran nazar merupakan 
pengakuan bahwa si penyembah mempunyai kewajiban moral terhadap Tuhan. (Rowley \& Cairns, 2012).

Tujuan nazar adalah untuk menyenangkan hati Allah atau merupakan ucapan syukur kepada Allah. Menurut Alkitab, nazar tidak dimaksudkan sebagai bujukan atau paksaan kepada Allah. Dalam peristiwa Absalom terbaca tentang nazar (2 Sam. 15:7). Absalom memenuhi nazar yang dibuatnya dengan mempersembahkan korban atau syelamim di Hebron. Sewaktu Daud mendengar tentang nazar Absalom, Daud segera setuju bahwa nazar itu harus dibayar. Dengan demikian membayar nazar berarti membalas kasih Tuhan dengan ucapan syukur dan tidak melupakan segala kebaikan Tuhan.

Berseru (ayat 15). "Berserulah kepada-Ku pada waktu kesesakan, Aku akan meluputkan engkau, dan engkau akan memuliakan Aku." Dalam versi lbrani: hrt mwoy 'rq (qara' yowm tsarah).

Kata Ibrani "berseru" q[;z, (za'aq), yakni bentuk verb, qal imperative, masculine singular suffix $1^{\text {st }}$ person singular, yang berarti berbicara, berkonsentrasi dan membuka hati untuk mendengar suara dan kehendak Tuhan. (Strong, 1986). Kata ini dijumpai dalam tubuh mazmur sebanyak 30 kali. Istilah ini terdapat sebagai judul pada 17; 86; 90; 102; 142 dan pada 72:20. Barth dan Pareira menuliskan, "Istilah aslinya berarti doa yang dipanjatkan dalam kesusahan dan kesesakan". (Barth \& Pareira, 1984, p. 36). 
Doa merupakan perlengkapan senjata Allah dan merupakan merupakan unsur penting dalam ibadah (Kadjakoro, 2019). Banyak dari mazmur-mazmur yang merupakan doa, walaupun hanya ada 5 mazmur saja disebut "doa" dalam judulnya (Mzm.17, 86, 90, 102, 142-, juga Hab. 3). (Rowley \& Cairns, 2012). Di luar Kitab Mazmur pun terdapat banyak doa dalam Perjanjian Lama. Jadi, berseru berarti berdoa kepada Tuhan dengan sikap menyadari ketidakmampuan diri sendiri dan mengakui akan pertolongan dari Tuhan sehingga Allah dimuliakan.

Hidup Menurut Ketetapan Allah. Allah mencela umat-Nya yang setia menyelidiki ketetapan-Nya. Hal ini merupakan suatu ironi karena pada bagian-bagian lain Allah menghendaki umat-Nya mengenal ketetapan- ketetapan-Nya. Dalam ayat 16, "Apakah urusanmu menyelidiki ketetapan-Ku". KJV: What hast thou to do to declare my statutes.

Kata Ibrani menyelidiki "rq;x;"(khaqar), yaitu bentuk verb, masculine, dipakai sebanyak 161 kali yang dalam bahasa Inggris declare yang berarti mengumumkan sedangkan kata Ibrani "rb;d;" (davar) artinya Firman, ketetapan, peraturan atau hukum (Bakker, 2012) yaitu bentuk noun, masculine, dipakai 127 kali yang dalam bahasa Inggris "statutes" berarti undang-undang, hukum. Hidup menurut ketetapan Tuhan berarti hidup dengan cara menuruti aturan atau hukum-hukum Tuhan.

Kebanyakan orang Kristen memahami ibadah itu sebagai suatu rutinitas saja, sehingga gagal mengalami makna ibadah yang sejati. (Tison $\frac{\text { \& Djadi, 2013). Seperti yang dikatakan oleh Longman, "Ibadah di }}{230}$ 
kebanyakan gereja merupakan sebuah tontonan saja." (Longman III, 1992, p. 96). Hal demikian juga terjadi pada sebagian dari mahasiswa STAKN Kupang yang pada pengamatan dan hasil wawancara penulis bahwa masih ada mahasiswa yang mengikuti ibadah karena rutinitas, karena dorongan atau pengaruh orang lain, karena motivasi atau alasan yang lain. Oleh karena itu perlu untuk mengetahui Tingkat Pemahaman Mahasiswa STAKN Kupang Semester V Mengenai Konsep Ibadah yang benar.

Mengacu pada latar belakang permasalahan masalah, maka dalam penelitian ini peneliti merumuskan masalah yaitu: Sejauh mana Tingkat Pemahaman Mahasiswa STAKN Kupang Semester V Mengenai Konsep Ibadah Menurut Mazmur 50?

\section{METODE}

Penelitian ini menggunakan tipe penelitian kombinasi. Metode kualitatif (eksegese ayat) dilakukan untuk mendapatkan indikator yang akan diukur. Kemudian dilanjutkan dengan pendekatan kuantitatif dalam bentuk survey. Survei adalah penelitian yang digunakan pada populasi besar maupun kecil, tetapi data yang dipelajari adalah data dari sampel yang diambil dari populasi tersebut, sehingga ditemukan kejadian-kejadian relatif, distribusi dan pengaruh dan hubungan-hubungan antar variable. (Kerlinger \& Lee, 2000). Dalam penelitian ini, populasi adalah keseluruhan Mahasiswa Semester V Jurusan Pendidikan Agama Kristen STAKN 
Kupang yang berjumlah sekitar 300 orang. Adapun dari populasi tersebut penentuan sampel menggunakan Nomogram Herry King, sehingga jumlah sampel dari populasi dengan taraf kesalahan 5\% adalah sebanyak 143 . (Sugiyono, 2015).

Pengumpulan data di lapangan dilakukan dengan menggunakan kuesioner. Data yang diperoleh dari hasil penelitian dianalisis dengan prosedur dan teknik statistik. Pengolahan data dilakukan dengan bantuan program Statistical Product and Servise Solution (SPSS) versi 20. Data hasil penelitian yang telah diperoleh kemudian ditabulasi dengan menggunakan microsof excel kemudian dideskripsikan berdasarkan setiap indikator. Untuk melihat distribusi data apakah normal maka dilakukan uji normalitas. Setelah itu dilakukan Uji hipotesis dengan Uji t satu sampel (one-sample t-test).

Hipotesa dalam penelitian ini yaitu:

Hipotesis Nol $\left(\mathrm{H}_{0}\right)$ : Tingkat Pemahaman Mahasiswa STAKN Kupang Semester V Mengenai Konsep Ibadah Menurut Mazmur 50:1-23 adalah lebih besar atau sama dengan $75 \%$ dari yang diharapkan $\left(\mathrm{H}_{0}: \mathrm{m} \geq\right.$ $75 \%)$.

Hipotesis alternative $\left(\mathrm{H}_{\mathrm{a}}\right)$ : Tingkat Pemahaman Mahasiswa STAKN Kupang Semester V Mengenai Konsep Ibadah Menurut Mazmur 50:1-23 adalah lebih kecil dari $75 \%$ dari yang diharapkan $\left(\mathrm{H}_{0}: \mathrm{m}<75 \%\right)$.

\section{HASIL}




\section{Deskripsi Data}

Dalam penelitian ini dibagikan kuesioner kepada 143 responden. Data hasil penelitian tersebut kemudian ditabulasi. Selanjutnya adalah data dari variable konsep ibadah menurut mazmur 50:1-20 tersebut disajikan dalam bentuk deskripsi data seperti pada table berikut:

Tabel 1 Konsep Ibadah menurut Mazmur 50:1-23

\begin{tabular}{|c|c|c|}
\hline \multirow{2}{*}{$\mathrm{N}$} & Valid & 143 \\
\cline { 2 - 3 } & Missing & 0 \\
\hline Mean & 61.1399 \\
\hline Median & 60.0000 \\
\hline Mode & 59.00 \\
\hline Std. Deviation & 5.27765 \\
\hline Minimum & 49.00 \\
\hline Maximum & 70.00 \\
\hline Sum & $\mathbf{8 7 4 3 . 0 0}$ \\
\hline \multicolumn{2}{|c|}{} \\
\hline
\end{tabular}

Dari deskripsi data variable Konsep Ibadah menurut Mazmur 50:123 dengan responden sebanyak 43 orang, ditemukan mean sebesar 61,1399, Median sebesar 60.000, Mode sebesar 59,00, standar deviasi sebesar 5,27765, angka minimum adalah 49,00, angka maksimum adalah 70.00 dan Sum sebesar 8743.00. Dapat dilihat dalam Histogram sebagai berikut: 
Tabel 2. Konsep Ibadah menurut Mazmur 50:1-23

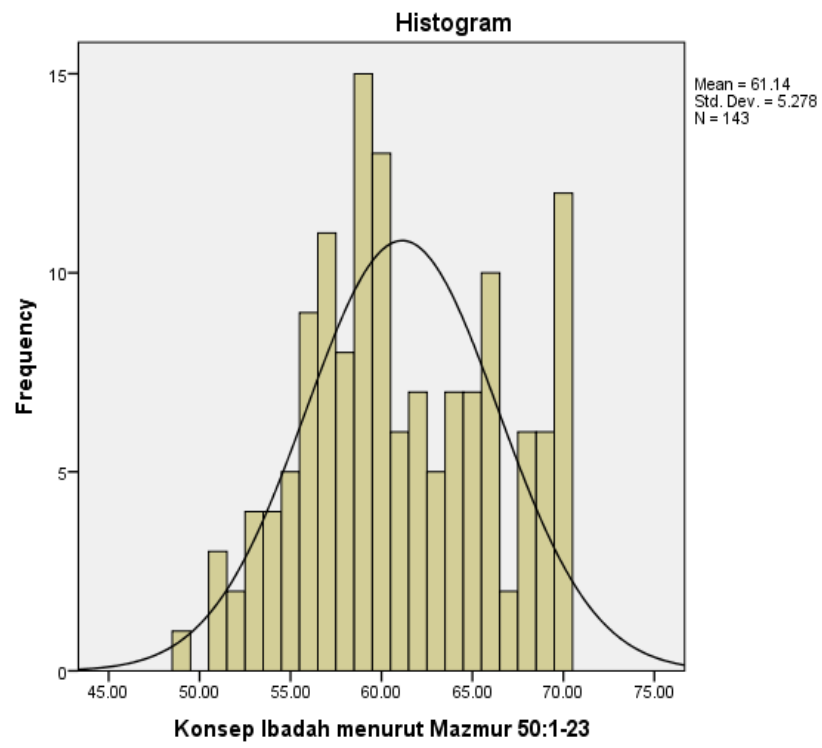

\section{Analisis Data dan Uji Hipotesis}

Dalam penelitian ini terdapat hipotesis yang akan diuji, dengan menggunakan bantuan SPSS 20 yakni Tingkat pemahaman mahasiswa STAKN Kupang Semester $\mathrm{V}$ mengenai konsep ibadah menurut Mazmur 50:1-23 yaitu lebih besar atau sama dengan $75 \%$ dari yang diharapkan.

Skor ideal untuk Tingkat pemahaman mahasiswa STAKN Kupang Semester $\mathrm{V}$ mengenai konsep ibadah menurut Mazmur 50:1-23 adalah $5 \times 14 \times 143=10010$ sehingga rata-ratanya adalah 10010:16=70. Untuk variable Tingkat pemahaman mahasiswa STAKN Kupang Semester V mengenai konsep ibadah menurut Mazmur 50:1-23 (Variabel Mandiri) dihipotesiskan lebih besar atau sama dengan $75 \%$ dari nilai ideal, hal ini sama dengan $0,75 \times 70=52,5$ 
Untuk hipotesis statistiknya, Ho memprediksi $\mu$ (Nilai yang dihipotesiskan) lebih rendah atau sama dengan $75 \%$ dari skor ideal. Ha lebih besar atau sama dengan $75 \%$ dari skor ideal. Hasil pengolahan dengan menggunakan rumus t-test satu sampel adalah seperti nampak pada tabel 3 di bawah ini.

Tabel 3. Hasil Pengolahan Data

\begin{tabular}{|c|c|c|c|c|c|c|c|}
\hline & \multicolumn{7}{|c|}{ One-Sample Statistics } \\
\hline & & & & $\mathrm{N}$ & Mean & Std. Deviation & $\begin{array}{l}\text { Std. } \\
\text { Mean }\end{array}$ \\
\hline & $\begin{array}{l}\text { Konsep I } \\
\text { Mazmur } 5\end{array}$ & $\begin{array}{l}\text { badah } \\
0: 1-23\end{array}$ & menurut & 143 & 61.1399 & 5.27765 & .44134 \\
\hline \multicolumn{8}{|c|}{ One-Sample Test } \\
\hline & & \multicolumn{6}{|c|}{ Test Value $=52.5$} \\
\hline & & \multirow{2}{*}{\multicolumn{2}{|c|}{$\mathrm{T}$}} & \multirow[t]{2}{*}{$\begin{array}{l}\text { Sig. } \\
\text { tailed) }\end{array}$} & \multirow[t]{2}{*}{$\begin{array}{l}\text { (2- } \text { Mean } \\
\text { Difference }\end{array}$} & $\begin{array}{l}95 \% \\
\text { Interval } \\
\text { Difference }\end{array}$ & $\begin{array}{l}\text { Confidence } \\
\text { of the }\end{array}$ \\
\hline & & & & & & Lower & Upper \\
\hline $\begin{array}{l}\text { Konsep } \\
\text { menurut } \\
50: 1-23\end{array}$ & $\begin{array}{l}\text { Ibadah } \\
\text { Mazmur }\end{array}$ & 19.576 & 142 & .000 & 8.63986 & 7.7674 & 9.5123 \\
\hline
\end{tabular}

Dari hasil tersebut ditemukan harga $t=19,576$, harga $t$ tersebut selanjutnya dibandingkan dengan harga t table dengan derajat kebebasan $(\mathrm{d} k)=\mathrm{n}-1=(143-1=142)$ dengan margin eror $\alpha=5 \%$ untuk one tail test. Berdasarkan $\mathrm{dk} 142$ dan $\alpha=5 \%$ harga t table untuk one tail test $=0,65566$. Dengan demikian, karena $t$ hitung lebih besar dari $t$ table atau jatuh pada penerimaan $\mathrm{Ha}(19,576>0,65566)$ maka Ha diterima dan Ho ditolak.

Jadi Hipotesis yang menyatakan bahwa Tingkat pemahaman mahasiswa STAKN Kupang Semester V mengenai konsep ibadah menurut Mazmur 50:1-23 lebih besar atau sama dengan 75\% dari yang 
diharapkan dapat diterima. Dari perhitungan rata-rata sampel Tingkat pemahaman mahasiswa STAKN Kupang Semester $V$ mengenai konsep ibadah menurut Mazmur 50:1-23 didapatkan nilai perbandingan total nila data hasil penelitian yaitu sebesar $\mathbf{8 7 4 3}$ dibandingkan dengan skor ideal sebesar 10010 maka diperoleh hasil sebesar 0,8734 atau $\mathbf{8 7 , 3} \%$ dari yang diharapkan.

\section{PEMBAHASAN}

Berdasarkan hasil analisis data dan pengujian hipotesis didapatkan bahwa harga t hitung $=\mathbf{1 9 , 5 7 6}$ dan harga $\mathrm{t}$ table untuk one tail test dengan dk $142=0,65566$. Dengan demikian, karena $t$ hitung lebih besar dari $t$ table atau jatuh pada penerimaan $\mathrm{Ha}(19,576>0,65566)$ maka Ha diterima. Artinya hipotesis bahwa Tingkat pemahaman Mahasiswa STAKN Kupang Semester $V$ mengenai konsep ibadah menurut Mazmur 50:1-23 lebih besar atau sama dengan $75 \%$ dari yang diharapkan dapat diterima

Berdasarkan hasil analisis data tersebut ditemukan bahwa Tingkat pemahaman Mahasiswa STAKN Kupang Semester V mengenai konsep ibadah menurut Mazmur 50:1-23 adalah sebesar 87,3\%.

\section{KESIMPULAN}

Hasil dari penelitian terhadap tingkat pemahaman mahasiswa STAKN Kupang semester $V$ mengenai konsep ibadah menurut Mazmur 50:1-23 menunjukkan bahwa tingkat pemahaman mahasiswa tersebut cukup baik. Oleh sebab itu disarankan agar mereka dapat 
mengembangkan potensi yang mereka miliki untuk pelayanan pekerjaan Tuhan. Selain itu untuk peneliti-peneliti berikut agar melakukan penelitian dengan metode yang sama untuk tema yang berbeda untuk mengukur tingkat pemahaman mahasiswa tentang pokok-pokok pembahasan tertentu.

\section{DAFTAR PUSTAKA}

Bakker, D. F. L. (2012). Sejarah kerajaan Allah 1. Jakarta: BPK Gunung Mulia.

Barth, M. C., \& Pareira, B. A. (1984). Tafsiran Alkitab: Pembimbing kepada Mazmur I / M.C. Barth dan B.A. Pareira. Jakarta: BPK Gunung Mulia.

Barth, M. C., \& Pareira, B. A. (1999). Tafsiran Alkitab-Kitab Mazmur 1-72. Jakarta: BPK Gunung Mulia.

Bergant, D. C., \& Karris, R. J. (2004). Tafsir Alkitab Perjanjian Baru. Yogyakarta: Kanisius.

Douglas, D. (Ed.). (2003). Ensiklopedi Alkitab Masa Kini Jilid I: A-L. Jakarta: Yayasan Komunikasi Bina Kasih/OMF.

Kadjakoro, Y. (2019). Konsep Prajurit Allah Berdasarkan Efesus 6:10-20 dan Implementasinya Dalam Kehidupan Orang Percaya. Jurnal IImiah Religiosity Entity Humanity (JIREH), 1(1), 40-56.

KBBI. (2016). KBBI - Kamus Besar Bahasa Indonesia. In Kbbi.Kemdikbud.Go.Id (3rd ed.). Jakarta: Balai Pustaka.

Kerlinger, F. N., \& Lee, H. B. (2000). Foundations of behavioral research. Forth Worth: Harcout College Publisher.

Longman III, T. (1992). Bagaimana Menganalisa Kitab Mazmur. Malang: SAAT.

Pfeiffer, C. F., \& Harrison, E. F. (Eds.). (2009a). Tafsiran Alkitab Wycliffe Volume 1, Kejadian - Ester. Malang: Penerbit Gandum Mas.

Pfeiffer, C. F., \& Harrison, E. F. (Eds.). (2009b). Tafsiran Alkitab Wycliffe 
Volume 2, Ayub-Maleakhi. Malang: Gandum Mas.

Rowley, H. H., \& Cairns, I. (2012). Ibadat Israel kuno. Jakarta: BPK Gunung Mulia.

Santosa, E. B. (2012). Dinamika Roh Kudus dalam Ibadah Pentakosta. Jurnal Antusias, 2(1), 160-181.

Setiawan, R. (2004). Tujuh Pemahaman Alkitab Tentang Ibadah. Jakarta: BPK Gunung Mulia.

Sihotang, S. H. (2006). Kasus-kasus dalam perjanjian lama. Bandung: Kalam Hidup.

Simanjuntak, A. (1985). Tafsiran Alkitab Masa Kini. Jakarta: BPK Gunung Mulia.

Stamps, D. C. (1999). Alkitab Penuntun Hidup Berkelimpahan. Malang: Gandum Mas.

Strong, J. (1986). The Exhaustive Concordance of The Bible. New York: MacDonald Company .

Sugiyono, S. (2015). Metode Penelitian Kombinasi (Mixed Methods). Bandung: Alfabeta.

Sumarto, Y. (2019). Tinjauan Teologis Tentang Ibadah Bagi Pelaksanaan Misi Allah. Jurnal Jaffray. https://doi.org/10.25278/jj71.v17i1.312

Tison, T., \& Djadi, J. (2013). Pengajaran Tentang Ibadah Berdasarkan Surat Ibrani 10:19-25 Dan Implimentasinya Dalam Kehidupan Orang Percaya Pada Masa Kini. Jurnal Jaffray. https://doi.org/10.25278/jj1.v11i1.67

White, J. F. (2011). Pengantar Ibadah Kristen. Jakarta: BPK Gunung Mulia.

Wongso, P. (1984). Tafsiran Kitab Mazmur. Malang: SAAT. 